\title{
Plasma Growth Hormone Concentration after a Single Intramuscular Injection of Human Growth Hormone
}

\author{
S. Douglas Frasier ${ }^{[22]}$, Gertrude Costin, Shun M. Ling, and Solomon A. Kaplan \\ Department of Pediatrics, University of Southern California School of Medicine, \\ Los Angeles County-University of Southern California Medical Center, and the Children's Hospital of Los Angeles, \\ Los Angeles, California, USA
}

\section{Extract}

We have investigated the concentration levels of growth hormone in plasma from six growth hormonedeficient patients who received human growth hormone (HGH) by intramuscular injection. The dose varied from 25 to $60 \mu \mathrm{g} / \mathrm{kg}$ body weight (38-92 mIU $/ \mathrm{kg}$ body weight). An attempt also was made following intramuscular injection in two patients to determine the amount of hormone excreted in the urine.

Growth hormone was detected in plasma $15 \mathrm{~min}$ after $\mathrm{HGH}$ was administered and reached peak levels $(65-154 \mathrm{ng} / \mathrm{ml}$ [mean $107.2 \pm 16.4 \mathrm{ng} / \mathrm{ml} \mathrm{SEM}$ ]) in the 2- or 4-h samples. In three patients, the concentration of growth hormone had fallen to basal levels at $12 \mathrm{~h}$; in all patients, $24 \mathrm{~h}$ after administration of $\mathrm{HGH}$ the levels of growth hormone were essentially undetectable. No growth hormone was detected in any urine samples.

The concentration of growth hormone in plasma observed after a single intramuscular injection differed markedly from the reported normal diurnal pattern.

\section{Speculation}

These studies suggest that the continued presence of growth hormone in plasma is not necessary for the promotion of growth in hypopituitary patients. Intermittent administration of growth hormone at weekly, biweekly or triweekly intervals may be associated with effects on the intracellular protein synthetic mechanisms that persist beyond the time of disappearance of growth hormone from the circulation.

\section{Introduction}

Data on the serum or plasma concentrations of human growth hormone (HGH) following an intramuscular injection are limited, and blood levels following a therapeutic dose of HGH have not been studied systematically. PARKer et al. [13], using a radioimmunoassay method, have shown that peak concentrations of growth hormone in plasma are found between 2 and $6 \mathrm{~h}$ following intramuscular injection of $10 \mathrm{mg} \mathrm{HGH}$ in normal adults. Concentrations in plasma returned to basal levels between 12 and $24 \mathrm{~h}$ after injection. This dosage is greater than the usual therapeutic range, and the observed levels may have been influenced by endogenous growth hormone secretion during the period of observation. 
The present study investigated the levels of growth hormone in plasma following an intramuscular injection of $\mathrm{HGH}$ at a therapeutic dose in six patients deficient in growth hormone. A preliminary report of this study has been published [5].

\section{Material and Methods}

Concentrations of growth hormone in plasma, following the initial intramuscular injection of $\mathrm{HGH}$, were determined in six patients with growth hormone deficiency. The clinical diagnosis was based in each patient by evident failure to increase the plasma concentration of growth hormone in response to insulin-induced hypoglycemia, as previously described [4]. Additionally, each patient had subsequently shown a significant response to the long-term administration of HGH. Patients were clinically and chemically euthyroid at the time of $\mathrm{HGH}$ administration.

Each patient was fasted overnight prior to challenge. At the time of testing, a needle was inserted into an antecubital vein and was left in place for the next $48 \mathrm{~h}$; a dilute heparin solution maintained patency. Immediately after obtaining a zero-time blood sample, 1 or $2 \mathrm{mg} \mathrm{HGH}$ were injected into the gluteal muscle. The growth hormone preparation used in these studies was National Pituitary Lot no. S-4 [19], which has a biological potency of $1.54 \mathrm{IU} / \mathrm{mg}$ ( $95 \%$ confidence limits 1.03-2.31 IU $/ \mathrm{mg}$ ). The dose of HGH administered to study patients varied from 25 to $60 \mu \mathrm{g} / \mathrm{kg}$ body weight (38-92 $\mathrm{mIU} / \mathrm{kg}$ body weight) (table I). $\mathrm{Pa}$ tients were subsequently allowed to have a regular hospital diet and normal activity. Blood was obtained at 15 and $30 \mathrm{~min}$ and $1,2,4,6,8,10,12,24,36$ and $48 \mathrm{~h}$ after $\mathrm{HGH}$ administration. Plasma was separated by centrifugation and stored at $-20^{\circ}$ until assayed. The concentration of growth hormone was measured by a radioimmunoassay method $[4,7]$, using a highly purified Wilhelmi HGH preparation (no. HS 840 FA) [20] as the standard.

Table I. Dosage of human growth hormone

\begin{tabular}{lcccc}
\hline Patient & \multicolumn{4}{c}{ Dose of growth hormone } \\
\cline { 2 - 5 } & $\mathrm{mg}$ & $\mu \mathrm{g} / \mathrm{kg}$ & $\mathrm{IU}$ & $\mathrm{mIU} / \mathrm{kg}$ \\
\hline $\mathrm{RS}$ & 1 & 25 & 1.5 & 38 \\
$\mathrm{MW}$ & 2 & 60 & 3 & 92 \\
$\mathrm{ML}$ & 2 & 55 & 3 & 85 \\
$\mathrm{JM}$ & 2 & 48 & 3 & 74 \\
JY & 2 & 45 & 3 & 69 \\
JG & 2 & 54 & 3 & 83 \\
\hline
\end{tabular}

An attempt was also made to determine the quantity of growth hormone excreted in the urine by two patients following an intramuscular injection of $\mathrm{HGH}$. Urine was collected at hourly intervals for the first $2 \mathrm{~h}$, at 2-h intervals for the next $10 \mathrm{~h}$, and at 6-h intervals thereafter for $24 \mathrm{~h}$. An aliquot from each collection was stored at $-20^{\circ}$ until assayed. The radioimmunoassay method was applied to unextracted urine. In three preliminary experiments $\mathrm{HGH}$ [20], at a concentration of $50 \mathrm{ng} / \mathrm{ml}$, was added to urine obtained from a hypophysectomized patient. Serial dilutions of this urine were assayed in duplicate. The resulting curves paralleled the assay standard curves in each experiment. Mean recovery of added growth hormone was $81 \%$. The sensitivity of the radioimmunoassay as applied to urine was $0.2 \mathrm{ng}$ growth hormone/ml; this assay will detect $1 \mathrm{ng}$ growth hormone/ml in urine assayed at a dilution of $1: 5$. Unknown urine samples were assayed in duplicate at three dilutions $(1: 5,1: 10$, and $1: 20)$. Nonspecific inhibition of antibody binding of $\mathrm{HGH}^{-131} \mathrm{I}$, which could be interpreted erroneously as a result of the presence of growth hormone, was not observed in the assay of urine from a hypophysectomized patient or in 19 unknown urine samples.

\section{Results}

The plasma concentrations of growth hormone following a single intramuscular injection are shown in table II and fig. 1. Plasma growth hormone was undetected after an overnight fast in the five patients from whom a sample was available; however, $15 \mathrm{~min}$ after the administration of $\mathrm{HGH}$, plasma growth hormune concentrations ranged between 5.2 and $29 \mathrm{ng} / \mathrm{ml}$. Growth hormone levels in plasma rose rapidly to peak concentrations of between 65 and $154 \mathrm{ng} / \mathrm{ml}$ (mean 107.2

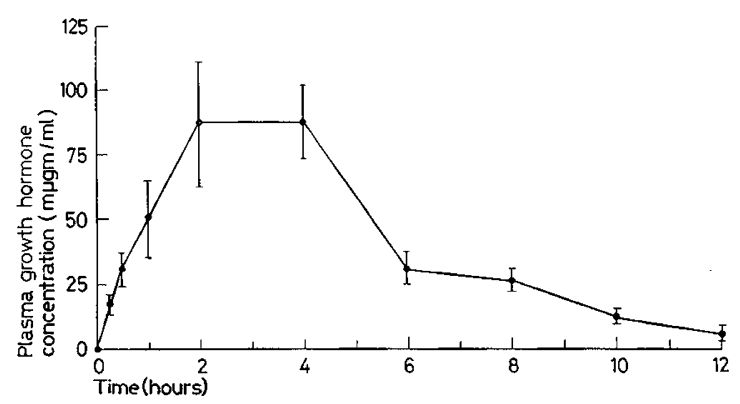

Fig. 1. Plasma concentration of growth hormone for the 12-h period following a single intramuscular injection of HGH in six patients deficient in growth hormone. The mean concentration is shown by closed circles, and \pm 1 SEM is enclosed in brackets. 
$\pm 16.4 \mathrm{ng} / \mathrm{ml} \mathrm{SEM})$. At $12 \mathrm{~h}$, the levels had fallen to basal values in three patients, and at 24 and $48 \mathrm{~h}$ growth hormone was not detected. The maximum plasma concentration observed during this time was $2.7 \mathrm{ng} / \mathrm{ml}$ (table II).

Growth hormone was not detected in any urine samples obtained following $\mathrm{HGH}$ administration. Since the assay will detect $1 \mathrm{ng}$ growth hormone $/ \mathrm{ml}$ of urine when assayed at a dilution of $1: 5$, the maximum possible concentration of growth hormone in each sample can be calculated from the volume of urine obtained over the period of sampling. The 24-h excretion of growth hormone in urine was less than $3.75 \mu \mathrm{g}$ in patient RS, and the 12-h excretion was less than $7.5 \mu \mathrm{g}$ in patient JG. Thus, following injection in these patients, excretion of growth hormone in the urine was less than $0.42 \%$ of the injected dose over $24 \mathrm{~h}$ and less than $0.36 \%$ over $12 \mathrm{~h}$, respectively.

\section{Discussion}

HunTER and Rigal [11] have investigated the normal diurnal variation in plasma concentration of growth hormone in children and adolescents. In these studies, the plasma concentration showed a pattern of postprandial peaks during the day and spontaneous peaks during the night. The concentration in plasma was generally lower than $20 \mathrm{ng} / \mathrm{ml}$, and in only one subject reached the level of $50 \mathrm{ng} / \mathrm{ml}$ during a 24-h period. The pattern of plasma concentrations observed after a single intramuscular injection was markedly different from the reported normal diurnal pattern. For six hours after $\mathrm{HGH}$ was injected ( 1 or $2 \mathrm{mg}$ ), the plasma concentrations were in the range usually found in acromegaly $[1,8,9]$.

The applicability of the radioimmunoassay technique to the measurement of growth hormone in urine is controversial. Using this method, normal values reported for the amount of growth hormone excreted in urine varied considerably among laboratories $[2,12$, 16]. A recent paper [6] suggests that substances that inhibit binding of tracer growth hormone and antibody are present in normal urine. Nonspecific inhibition of the radioimmunoassay system, not demonstrated in the present study, would give erroneously high values for urinary growth hormone.

The absence of detectable growth hormone in urine following an intramuscular injection of $\mathrm{HGH}$ confirms the findings of NAJJAR and BLIzzARD [12]. They administered 5 or $10 \mathrm{mg} \mathrm{HGH}$ to hypopituitary patients and detected $0.1-0.3 \%$ of the injected dose in subsequent 24-h urine collections. The rapid disappearance of growth hormone from plasma following a single injection, and the absence of the injected dose in the

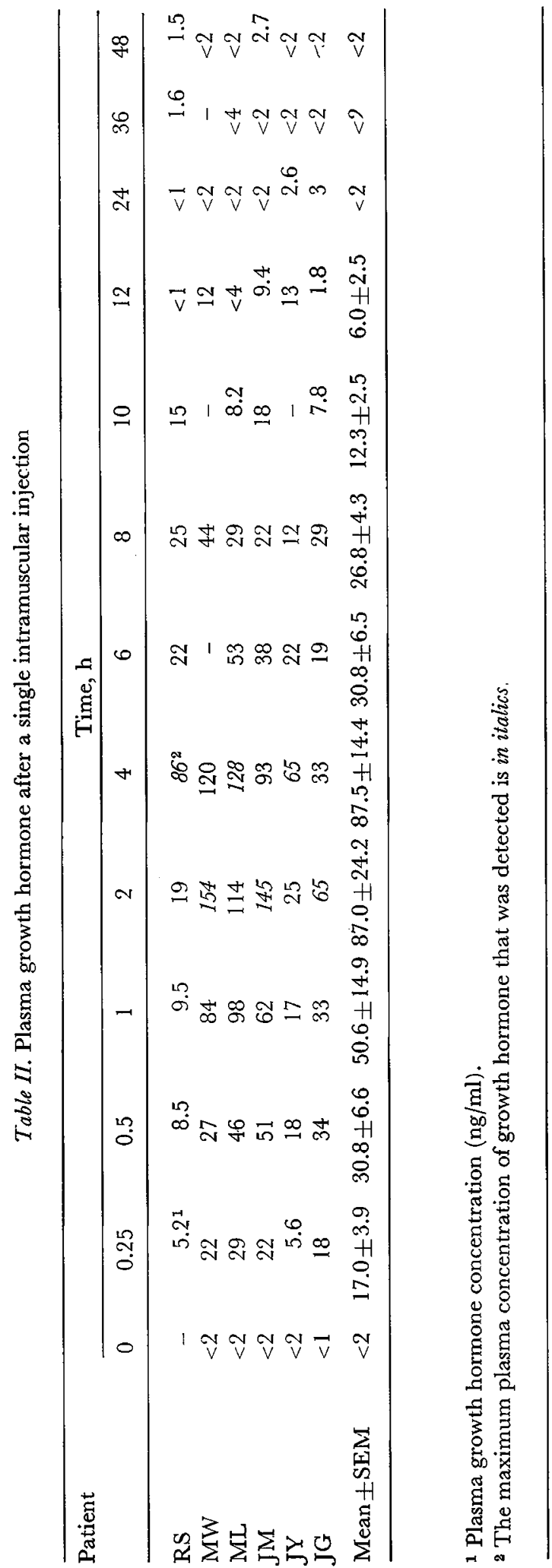


urine, suggest rapid intracellular distribution of hormone. Another possible explanation for this disappearance is an alteration of administered growth hormone by proteolytic enzymes in plasma, which would alter the immunoreactivity of $\mathrm{HGH}$ and produce substances that, while active in promoting linear growth, are not detected by radioimmunoassay.

Human growth hormone injected at biweekly or triweekly intervals promoted linear growth in hypopituitary patients [10,14,17], and one report [15] suggested that weekly injections are also effective. Our observations indicated that HGH was detectable at significant concentrations in the plasma of hypopituitary patients for a maximum of $24 \mathrm{~h}$ following a single intramuscular injection. This finding and the results of investigative $\mathrm{HGH}$ therapy suggest that growth hormone has an effect on the intracellular protein synthesis that persists after the disappearance of growth hormone from the circulation. The observation of Florini and Breuer [3] that increased RNA polymerase activity in the rat reaches a peak in skeletal muscle $18 \mathrm{~h}$ after the injection of growth hormone supports this hypothesis. Increased protein synthetic activity of muscle ribosomes persists for $48 \mathrm{~h}$ after the injection.

\section{Summary}

Plasma concentrations of growth hormone following a single intramuscular injection of $\mathrm{HGH}$ were measured in six patients deficient in growth hormone. Growth hormone was detected in plasma 15 min after injection, and levels usually found in acromegaly were observed for 6-8 $\mathrm{h}$ after injection. Plasma levels returned to control values $24 \mathrm{~h}$ after $\mathrm{HGH}$ administration, but the pattern is markedly different from the normal diurnal variation of growth hormone concentration in plasma. Growth hormone was not detected in urine after an intramuscular injection of HGH.

\section{References and Notes}

1. Boden, G.; Soeldner, J.S.; Steinke, J. and ThorN, G.W.: Serum human growth hormone (HGH) response to IV glucose: Diagnosis of acromegaly in females and males. Metabolism 17: 1-9 (1968).

2. Collrp, P.J.: Immunoassay and bioassay of urinary human growth hormone (Abstract). 36th Meet. Soc. Pediat. Res. Atlantic City, N.J. 1966.

3. Florini, J.R. and Breuer, C. B.: Amino acid incorporation into protein by cell-free systems from rat skeletal muscle. Effects of pituitary growth hormone on activity of ribosomes and ribonucleic acid polymerase in hypophysectomized rats. Biochemistry 5: 1870-1876 (1967).

4. Frasier, S.D.: The serum growth-hormone response to hypoglycemia in dwarfism. J. Pediat. 71: 625-638 (1967).

5. Frasier, S.D.; Costin, G.; Ling, S.M. and KAPLAN, S. A.: Plasma growth hormone after a single intramuscular injection (Abstract). Pediat. Res. 2: 310 (1968).

6. Girard, J. and Greenwood, F. C.: The absence of intact growth hormone in urine as judged by radioimmunoassay. J. Endocrin. 40: 493-503 (1968).

7. Gurck, S. M.; Roth, J.; Yalow, R.S. and Berson, S.A.: Immunoassay of human growth hormone in plasma. Nature, Lond. 199: 784-787 (1963).

8. Glick, S. M.; Roth, J.; Yalow, R. S. and Berson, S.A.: The regulation of growth hormone secretion. Recent Progr. Hormone Res. 21: 241-270 (1965).

9. Hartog, M.; Gaafar, M.A.; Meisser, B. and FRASER, R.: Immunoassay of serum growth hormone in acromegalic patients. Brit. med.J. ii: 1229 1232 (1964).

10. Hennemann, P.H.: The effect of human growth hormone on growth of patients with hypopituitarism. J. amer. med. Ass. 205: 828-836 (1968).

11. Hunter, W.M. and Rigal, W.M.: The diurnal pattern of plasma growth hormone concentration in children and adolescents. J. Endocrin. 34: 147153 (1966).

12. NajJar, S.S. and Blizzard, R.M.: Excretion of human growth hormone (HGH) in the urine of normal adults and children (Abstract). 36th Meet. Soc. Pediat. Res., Atlantic Gity, N.J. 1966.

13. Parker, M.L.; Utiger, R.D. and Daughaday, W.H.: Studies of human growth hormone. II. The physiological disposition and metabolic fate of human growth hormone in man. J. clin. Invest. 41 : 262-268 (1968).

14. Prader, A.; Zachmann, M.; Polex, J.R.; Illig, R. and Székx, J.: Long-term treatment with human growth hormone (Raben) in small doses: Evaluation of 18 hypopituitary patients. Helv. paediat. Acta 22: 423-440 (1967).

15. Rosenbloom, A. L. : Growth hormone replacement therapy. J. amer. med. Ass. 198: 364-368 (1966).

16. Sakuma, M.; Irie, M.; Shizume, K.; Tsushima, T. and MAKAO, K.: Measurement of urinary human growth hormone by radioimmunoassay. J.clin. Endocrin. 28: 103-105 (1968).

17. TAnner, J.M. and Whitehouse, R.H.: Growth response of 26 children with short stature given human growth hormone. Brit.med.J. ii: 69-75 (1967). 
18. Supported by State of California Department of Mental Hygiene Grant no. 14-38 and the United States Public Health Service Clinical Research Center Grants nos. FR-00043 and FR-00086.

19. Human growth hormone preparation no. S-4 provided by the National Pituitary Agency, National Institute of Arthritis and Metabolic Diseases.

20. Human growth hormone preparation no. HS 840 FA provided by Dr. Alfred Wrlmelmi through the
National Pituitary Agency, National Institute of Arthritis and Metabolic Diseases.

21. Technical assistance was provided by Mrs. JEAN Marie Hilburn, B.S.

22. Requests for reprints should be addressed to: S. Douglas Frasier, M.D., Children's Division (4E8), Los Angeles County-University of Southern California Medical Center, 1200 North State Street, Los Angeles, Cal. 90033 (USA). 